University of Nebraska - Lincoln

DigitalCommons@University of Nebraska - Lincoln

1999

\title{
Factors Related to the Recovery of Subalpine Woodland on Mauna Kea, Hawaii
}

Steven C. Hess

Montana State University - Bozeman

Paul C. Banko

U.S. Geological Survey

Gregory J. Brenner

U.S. Geological Survey

James D. Jacobi

U.S. Geological Survey

Follow this and additional works at: https://digitalcommons.unl.edu/usgsstaffpub

Hess, Steven C.; Banko, Paul C.; Brenner, Gregory J.; and Jacobi, James D., "Factors Related to the Recovery of Subalpine Woodland on Mauna Kea, Hawaii" (1999). USGS Staff -- Published Research. 637. https://digitalcommons.unl.edu/usgsstaffpub/637

This Article is brought to you for free and open access by the US Geological Survey at DigitalCommons@University of Nebraska - Lincoln. It has been accepted for inclusion in USGS Staff -- Published Research by an authorized administrator of DigitalCommons@University of Nebraska - Lincoln. 


\title{
Factors Related to the Recovery of Subalpine Woodland on Mauna Kea, Hawaii ${ }^{1}$
}

\author{
Steven C. Hess ${ }^{2}$, Paul C. Banko, Gregory J. Brenner, and James D. Jacobi \\ U.S.G.S. Biological Resources Division, Pacific Island Ecosystems Research Center, P.O. Box 44, Hawaii \\ National Park, Hawaii 96718 , U.S.A.
}

\begin{abstract}
We measured mature tree and sapling density, tree associations, crown size, age structure, recovery from ungulate browsing, and grass cover at four study sites in two types of subalpine woodland on Mauna Kea volcano, island of Hawaii. Beginning in 1981, introduced ungulates were reduced in number to allow regeneration of Sophora chrysophylla (mamane) in habitat supporting the endangered Hawaiian finch, Loxioides bailleui (palila). We found Sophora regeneration at all four study sites, but regeneration was higher in mixed species woodland with codominant $M y$ oporum sandwicense (naio) than in areas where Sophora dominated. Regeneration of Myoporum was uniformly very low in comparison. Invasive grass cover, which suppresses Sophora germination, was highest in mid-elevation woodland where Sophora dominated. The distribution of mature and sapling Sophora were both related to study site, reflecting previous ungulate browsing and uneven recovery due to grasses. Densities of Sophora snags were not different among any of the sites, suggesting a more even distribution in the past. Selective browsing before ungulate reduction may have favored Myoporum over Sophora, leading to high densities of mature Myoporum in codominant woodland. After ungulate reduction, however, we found no pattern of competitive inhibition by Myoporum on regeneration of Sophora. Reduction of Myoporum is not likely to enhance habitat for Loxioides as much as supplemental plantings of Sophora, grass control, and continued ungulate eradication. Mid-elevation Sophora woodland areas, where Loxioides forage and nest in high densities, would benefit the most from these management actions.
\end{abstract}

Key words: browse damage; Hawaii; invasive grasses; Loxioides; mamane; palila; recovery; Sophora; subalpine woodland.

Dry roresis of ihe Hawaitan Islanus, like dry forests in other tropical regions, have been extensively altered by human activity (Murphy \& Lugo 1986, Cuddihy \& Stone 1990), and as in other tropical areas, Hawaiian dry forest avifaunas have fared worse than those of humid forests (Stotz et al. 1996). The endangered finch (Fringillidae: Drepanidinae), Loxioides bailleui Oustaler (palila), is now the only remaining endemic bird that requires dry forest, living exclusively in subalpine woodland of Mauna Kea volcano, island of Hawaii (Scott et al. 1986). Loxioides rely primarily on the green seeds of the endemic leguminous tree, Sophora chrysophylla Salisb. (Mamane), for food. They also eat Sophora flowers, flower buds, foliage flush (van Riper 1980a), and moth larvae that inhabit pods (Biological Resources Division, pers. comm.), and depend on Sophora for nesting and roosting sites. Loxioides were once more widely distributed in lowlands and on at least one other island before Polynesian contact (Olson \& James 1982). They are currentiy restricted to $139 \mathrm{~km}^{2}$, less than five per-

\footnotetext{
1 Received 15 September 1996; revision accepted 26 September 1997.

2 Present Address: Fish \& Wildlife Management Program, Montana State University, P.O. Box 173460, 301 D Lewis Hall, Bozeman Montana 59717-3460, U.S.A.
}

cent of their historical distribution (Scott $e t$ al. 1984, 1986; Jacobi et al. 1996).

Subalpine woodlands dominated by Sophora developed in the absence of herbivorous mammals, as did all other Hawaiian forests (Carlquist 1970). The largest remaining stand of Sophora subalpine woodland, a unique forest of the world, is on Mauna Kea volcano. Rain shadow effects of Mauna Kea and extreme substrate drainage account for the semiarid aspect of the woodland. All of the dominant tree species are endemic to the Hawaiian Islands where it is cooler than lowland tropical or subtropical dry forests (Murphy \& Lugo 1986), with frequent freezing temperatures, relatively aseasonal precipitation, and substantial cloud-water interception (Juvik \& Nullet 1993, Juvik et al. 1993). Herbivorous mammals, including feral sheep (Ovis aries), mouflon sheep (O. musimon), feral goats (Capris hircus), feral cattle (Bos taurus), and feral horses (Equus caballus) repeatedly have reached high population densities on Mauna Kea and suppressed regeneration of Sophora since their introductions beginning in 1793. (Hartt \& Neal 1940, Warner 1960, Giffin 1976, 1982; Scowcroft \& Giffin 1983, Scowcroft \& Sakai 1983, Scowcroft 1983, Juvik \& Juvik 1984, Mountainspring et al. 1987). Alien grasses, such as Dactylus glom- 
erata, Holcus lanatus, Anthoxanthum odoratum, and Poa pratensis, now dominate understory vegetation in subalpine woodland on Mauna Kea (Smith \& Tunison 1992, Amarasekare 1993, Williams 1994). Sophora facilitates grass growth by providing a high nutrient environment, with germination of Sophora being also suppressed by grasses (Williams 1994). Fires in subalpine woodland are rare natural events, but invasive grasses have added continuous fine fuels (Smith \& Tunison 1992), increasing the likelihood of intense fires that could result in the shortterm destruction of Loxioides habitat.

Selective browsing of Sophora by feral mammals may have caused increased densities of Myoporum sandwicense A. Gray (Myoporaceae; naio) in areas where these trees codominated (van Riper 1980b, Cuddihy \& Stone 1990). Hunting pressure caused feral mammals to concentrate browsing at high elevation and in other areas not accessible by road (Giffin 1976, 1982; Scowcroft \& Giffin 1983). The current pattern of Sophora distribution on Mauna Kea may have been affected by a combination of localized browsing, seedling suppression from introduced grasses, and possibly, competitive suppression from other native plants. These factors, as well as existing feral Ovis spp. populations in some areas, may currently control regeneration in subalpine woodland.

The recovery plan for Loxioides calls for sustaining and expanding Sophora forest and preventing further damage by removing, excluding, and fencing feral animals from Loxioides habitat (U.S. Fish and Wildlife Service 1986). Federal court rulings in 1979 and 1986 mandated removal of feral Ovis spp. and Capris to allow regeneration of Sophora trees for Loxioides. Monitoring of vegetation condition and trend was also recommended, but no monitoring programs were established after animals were reduced beginning in 1981 (Scowcroft \& Giffin 1983, Scott et al. 1986). Mountainspring et al. (1987), using semiquantitative methods, concluded that Sophora regeneration occurred in response to reduced browsing pressure. They also concluded that Sophora was replacing Myoporum in areas where the two species codominate. Reduction of Myoporum has been considered as a potential management action to improve Loxioides habitat with the implicit assumption that it limits Sophora through competition; however, there have been no studies to determine if such an interaction exists. If there is no negative association between these species, then Myoporum reduction is not likely to be an effective management action.

We measured mature tree and sapling density, tree associations, crown size, age structure, and grass cover to describe woodland structure and to identify factors correlated with Sophora recovery from ungulate browsing in habitat supporting Loxioides on the west slope of Mauna Kea. The objectives of this study were to determine: (1) if there are differences in regeneration, age structure, and crown size of Sophora related to woodland type, site, or elevation; (2) if Myoporum or grasses are negatively associated with Sophora regeneration; and (3) estimate current ungulate browse damage on Sophora regeneration. Additionally, this data establishes a background for habitat structure comparisons with subalpine woodland ecosystems in other areas on the island of Hawaii that are being considered for restoration of Loxioides.

\section{METHODS}

We used the point-centered quarter method, a transect-based distance method (Mueller-Dombois \& Ellenberg 1974), to estimate densities of all mature trees, saplings, and tree associations at four established Loxioides study sites on the west slope of Mauna Kea, island of Hawaii $\left(19^{\circ} 50^{\prime} \mathrm{N}\right.$, $\left.155^{\circ} 35^{\prime} \mathrm{W}\right)$. The four study sites were arranged on an elevational gradient that extends $1978-2816 \mathrm{~m}$ in dry subalpine woodland of the Mauna Kea Forest Reserve (Fig. 1).

Substrates were severely drained vitrandepts composed of volcanic cinder and ash with exposed basaltic lava flows. Surface substrate age was between 4000 and 14,000 years (Wolfe \& Morris 1996). Much of the organic soil layer has been lost to erosion and grazing since European colonization (Warner 1960). Temperature averages $11.1 \pm 1.5^{\circ}$ $\mathrm{C}$ annually and rainfall averages $511 \mathrm{~mm}$ (Juvik \& Nullet 1993). January through April and August are the wettest months with average rainfall $>50 \mathrm{~mm} /$ mo. June is the driest month with $<20 \mathrm{~mm} / \mathrm{mo}$ (Juvik, pers. comm.). In addition to rainfall, there is also substantial fog-drip interception by trees from a cyclic diurnal influx of humid, low elevation air that may account for as much as 38 percent additional precipitation (Juvik \& Nullet 1993).

The study sites were designated in order of descending elevation: upper, mid-elevation north, midelevation south, and lower. Although the mid-elevation north site overlapped 74 percent of the midelevation south site in altitiude, the sites contained different woodland types (Fig. 1). The upper and mid-elevation north sites were comprised almost exclusively of Sophora with 5-30 percent canopy cover, and the mid-elevation south and lower sites con- 


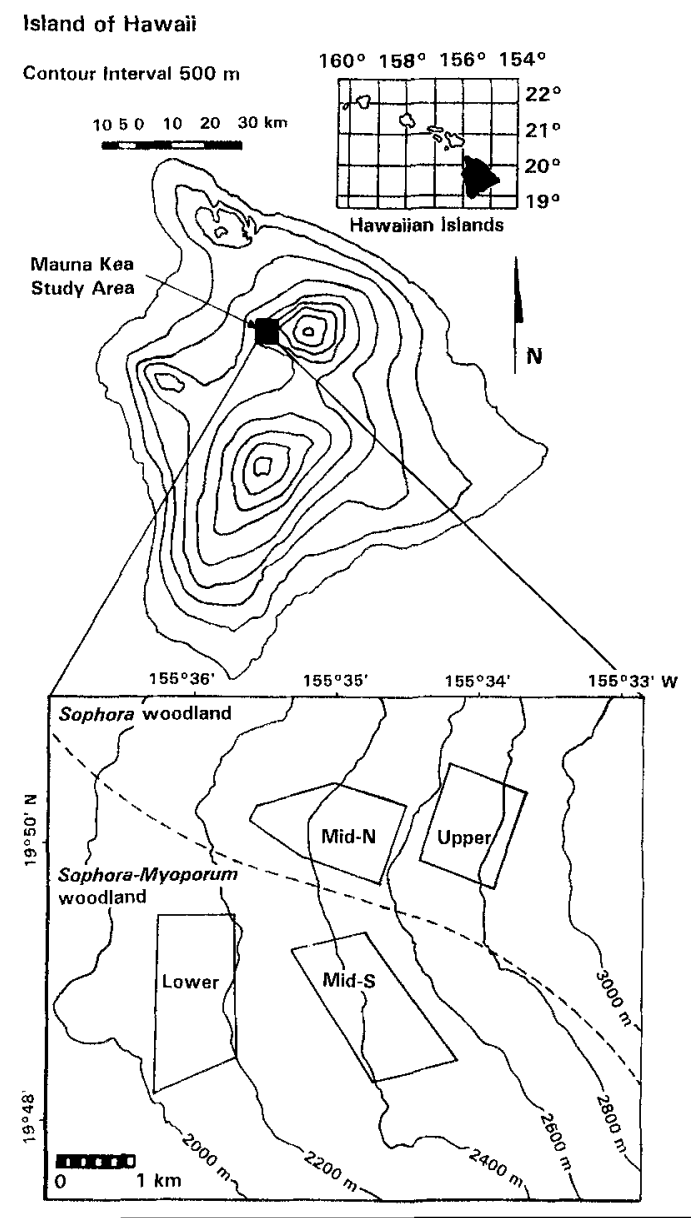

FIGURE 1. Map of study area with $200 \mathrm{~m}$ elevation contours, study sites, and approximate boundary of $S_{0-}$ phora woodland and mixed Myoporum-Sophora woodland on the west slope of Mauna Kea, Hawaii.

tained a high proportion of codominant Myoporum with as much as 60 percent total canopy cover. Overall canopy cover averaged 30 percent and canopy height was generally short $(3-10 \mathrm{~m})$. Other woodland species included in this study were $\mathrm{Do}$ donaed viscosa (Sapindaceae) and Chenopodium oabuense (Chenopodiaceae), which were found primarily in the mid-elevation south and lower elevation sites. Additional tree species present in subalpine woodlands of Mauna Kea but not encountered during sampling included: Chamaesyce olowaluana (Euphorbiaceae), Dubautia arborea (Asteraceae), and Santalanum ellipticum (Santalaceae). Vegetation in the study area was described previously by van Riper (1980b) and Scowcroft and Giffin (1983). Other subalpine areas on Mauna Kea have been described by Hartt and Neal (1940).
At each of the four sites, we selected three transects randomly to estimate tree and sapling density. Transect length varied $1050-1200 \mathrm{~m}$. In each study area, we randomly placed 20 point-centers along two transects and 10 point-centers along the third transect for a total of 50 point-centers per study site, except at the upper site where 20 point-centers were chosen for all three transects. Within each quarter, we selected the nearest mature tree of crown size $>2 \mathrm{~m}$ tall and the nearest sapling tree with a crown height $<2 \mathrm{~m}$ but $>0.5 \mathrm{~m}$. We also selected the nearest standing dead tree to each point that had attained a height $>2 \mathrm{~m}$. We measured the distance from each selected tree crown center to the sample point to $\pm 0.5 \mathrm{~m}$. We considered all conspecific stems emerging from the ground within a $1-\mathrm{m}$ radius of the selected individual to come from the same individual. Because Sophora trees have irregular growth forms and diameter may not be a reliable indicator of size or age, we used crown height and width as a measure of size. We measured the crown width to $\pm 0.5 \mathrm{~m}$ at the widest point for mature trees. We visually estimated crown height for mature trees to \pm 0.5 $\mathrm{m}$; observers were trained in height estimation to reduce errors. We measured elevation at each pointcenter with a Thommen handheld altimeter.

We estimated three age categories for all mature Sophora trees by the following method: (1) trees with recumbent dead branches were considered se-.nescent; (2) trees without dead recumbent branches, but having deeply fissured bark and lichens on the branches, were considered mature; and (3) trees with smooth bark and lacking lichens were considered young.

We randomly selected a transect from each site to estimate ungulate browse damage. We recorded the presence of recent browse damage on each of the trees selected for density estimation. We sampled grass cover at $30 \mathrm{~m}$ intervals on two transects to relate the association of grasses with tree regeneration. One transect bisected the upper and midelevation north sites and the other bisected the mid-elevation south and lower sites. We used a 1 $\mathrm{m}^{2}$ frame with $10 \times 10 \mathrm{~cm}$ cells to estimate the area within the frame containing grass cover of any species.

We calculated density estimates for each pointcenter with Pollard's (1971) formula for an unbiased population density estimate of the point-centered quarter method where $N_{\mathrm{p}}=$ the population density estimate, $n=$ the number of random points, and $r_{\mathrm{ij}}=$ the distance from the random point $i$ to the nearest organism in quadrant $j$. 
TABLE 1. Densities (no./ha ${ }^{l}$ ) of trees $<2 \mathrm{~m}$ tall but $>0.5 \mathrm{~m}$ tall, trees $>2 \mathrm{~m}$ tall, and snags of Sophora chrysophylla, Myoporum sandwicense, Chenopodium oahuense, Dodonaea viscosa, all species combined, and elevation at four sites on the west slope of Mauna Kea, Hawaii. Mean Sophora densities with the same superscripts are not significantly different (Tukey grouping, $\alpha=0.05$ ). Sophora snag densities did not differ among sites.

\begin{tabular}{|c|c|c|c|c|}
\hline Site & Upper & Mid-N & Mid-S & Lower \\
\hline Elevation range & $2816-2599 \mathrm{~m}$ & $2575-2317 \mathrm{~m}$ & $2437-2274 \mathrm{~m}$ & $2128-1978 \mathrm{~m}$ \\
\hline $\begin{array}{l}\text { Trees }<2 \mathrm{~m} \text { tall } \\
\text { Sophora } \\
\text { Myoporum } \\
\text { Chenopodium } \\
\text { Dodonaea }\end{array}$ & $\begin{array}{c}49.1 \\
48.5^{\mathrm{a}} \\
0.2 \\
0.4 \\
\end{array}$ & $\begin{array}{l}16.4 \\
16.0^{\mathrm{b}} \\
0.3 \\
0.1\end{array}$ & $\begin{array}{c}120.8 \\
21.7^{\mathrm{a}, \mathrm{b}} \\
1.2 \\
96.0 \\
1.2\end{array}$ & $\begin{array}{l}67.8 \\
36.9^{a} \\
3.1 \\
7.5 \\
0.3\end{array}$ \\
\hline $\begin{array}{l}\text { Trees }>2 \mathrm{~m} \text { tall } \\
\text { Sophora } \\
\text { Myoporum } \\
\text { Chenopodium }\end{array}$ & $\begin{array}{c}118.4 \\
118.4^{\mathrm{a}} \\
- \\
-\end{array}$ & $\begin{array}{c}51.3 \\
50.9^{\mathrm{b}} \\
0.3 \\
-\end{array}$ & $\begin{array}{l}77.9 \\
28.4^{\mathrm{b}} \\
48.7 \\
0.07\end{array}$ & $\begin{array}{c}249.8 \\
48.7^{1} \\
199.8 \\
-\end{array}$ \\
\hline $\begin{array}{l}\text { Snags } \\
\text { Sophora } \\
\text { Myoporum } \\
\text { Chenopodium }\end{array}$ & $\begin{array}{l}48.0 \\
48.0 \\
- \\
-\end{array}$ & $\begin{array}{l}27.7 \\
27.7 \\
- \\
-\end{array}$ & $\begin{array}{r}65.0 \\
42.3 \\
3.3 \\
19.5\end{array}$ & $\begin{array}{l}48.1 \\
21.6 \\
26.5 \\
-\end{array}$ \\
\hline
\end{tabular}

$$
N_{\mathrm{P}}=4(4 n-1) / \pi \sum\left(r_{i j}{ }^{2}\right)
$$

We calculated snag density at each point-center with Cottam and Curtis's (1956) formula adjusted for sampling a single individual at each point, where $Q_{1}=$ the distance to the nearest snag at a point and $\mathrm{MA}=$ the equivalent of the mean area occupied by snags in each of the four quarters: $Q_{1}$ $=0.5 \mathrm{VMA}$.

Analysis. - We tested mature Sophora tree and sapling densities for effects of site, elevation, and their interaction at each point-center by two-way ANOVA (SAS Institute 1985). Myoporum densities were tested only for differences among sites because of distinct distributional limits that do not correspond to elevation (van Riper 1980b). We used Tukey's studentized range test and ANOVA contrasts to determine which sites differed from each other, and the probability of difference. We analyzed crown size and grass cover in the same manner. Age categories between sites were compared with Chi-square tests. We log transformed all density data and square root transformed grass cover data before analysis.

\section{RESULTS}

SAPling Densities.-Sophora sapling densities differed among study sites (ANOVA, $P=0.002$, Table 1$)$, and were not related to elevation $(P>0.6)$. They were related, however, to the interaction of study site and elevation $(P<0.04)$. Sophora sapling densities were higher in the two mixed Myoporum-
Sophora study sites than in the two Sophora-dominated study sites $(P=0.021)$. The Sophora dominated mid-elevation north site did not differ from the mixed Myoporum-Sophora mid-elevation south site in Sophora sapling density $(P>0.21)$. Myoporum sapling density was extremely low and not significantly different among any of the sites.

Mature tree densitins.-Mature Sophora densities differed among study sites (ANOVA, $P<0.0001$; Table 1) and also were related to elevation $(P<$ 0.0001 ), but were not related to the interaction of study site and elevation $(P>0.09)$. Mature Sophora densities were higher on the upper study site $(P=0.021)$ than the three other study sites. They, however, did not differ between the two Sophoradominated sites and the two mixed Myoporum-Sophora sites $(P>0.16)$. Mature Myoporum densities were higher in the mid-elevation south and lower sites than the mid-elevation north and upper sites $(P<0.0001)$, where the species was virtually absent. Only one mature Myoporum tree was sampled above $2286 \mathrm{~m}$ elevation. Chenopodium oahuense occurred as mature trees only at the mid-elevation south site and only one individual of Dodonaea vis$\cos a>2 \mathrm{~m}$ tall was encountered.

SNAG DENSITIES.- There were no significant differences in Sophora snag densities between sites (ANOVA, $P>0.15$; Table 1). There were also no effects of elevation, site, or their interaction on $\mathrm{So}$ phora snag density. We did not encounter Myoporum or Chenopodium snags in the upper and mid-elevation north sites. 


\begin{tabular}{lrc}
\hline TABLE 2. & $\begin{array}{l}\text { Mean heights and widths }(m) \text { of Sophora } \\
\text { chrysophylla trees }>2 m \text { tall at four sites on } \\
\text { the west slope of Mauna Kea, Hawaii. Means } \\
\text { with the same superscripts are not significantly } \\
\text { different (Tukey grouping, } \alpha=0.05 \text { ). }\end{array}$ \\
\hline & $\begin{array}{l}\text { Sophora } \\
\text { hite }\end{array}$ & $\begin{array}{c}\text { Sophora } \\
\text { width }\end{array}$ \\
\hline Upper & $3.961^{\mathrm{a}}$ & $5.341^{\mathrm{a}}$ \\
Mid-N & $4.827^{\mathrm{b}}$ & $6.702^{\mathrm{b}}$ \\
Mid-S & $4.753^{\mathrm{b}}$ & $6.182^{\mathrm{b}} \mathrm{b}$ \\
Lower & $4.269^{\mathrm{a}}$ & $3.897^{\mathrm{C}}$ \\
\hline
\end{tabular}

Crown Sizl:s. - There was a significant effect of both site (ANOVA, $P<0.0001$; Table 2 ) and elevation $(P<0.0001)$ and also an interaction effect of site and elevation on mature Sophora tree height $(P<0.001)$. The upper site and the lower site contained significantly shorter mature Sophora trees overall than the two mid-elevation sites $(P<$ 0.001 ).

There was a significant effect of site (ANOVA, $P<0.0001$; Table 2) and an interaction effect of site and elevation on mature Sophora crown width $(P<0.0001)$, but there was no effect of elevation alone $(P=0.647)$. The upper, mid-elevation north, and mid-elevation south sites had significantly wider crowned trees than the lower site $(P$ $=0.041$ ).

Agr: catroories.-Sophora age distributions differed ( $\chi^{2}$ test, $P=0.003$; Table 3 ) between upper and lower sites, with the proportion of young trees much higher in the lower site than the upper site. The upper site also had over twice the proportion of mature trees than the lower site, while the proportion of senescent trees was similar between the upper and lower sites.

Browse IDAMAGE.-There was no detectable browse damage on Sophora on the upper and mid-elevation sites. In the lower site, 11 of $13(85 \%)$ mature trees and 11 of 13 saplings had browse damage. The bark of many young Sophora and Myoporum trees was stripped off; there was evidence of browsing on Sophora leaves, but no evidence of browsing on Myoporum leaves.

Grass Cover.-Grass cover differed by study site (ANOVA, $P<0.0001$; Fig. 2 ) and was also related to the interaction of study site and elevation $(P<$ $0.0001)$. Elevation alone was not related to grass cover $(P>0.33)$. The mid-elevation north site, where Sophora regeneration was lowest, had signif-
TABLE 3. Percent Sophora chrysophylla trees $>2 \mathrm{~m}$ tall) and sample sizes in three age categories at four sites on the west slope of Mauna Kea, Hawaii.

\begin{tabular}{lcccc}
\hline Site & $\begin{array}{c}\text { Sample } \\
\text { size }\end{array}$ & Young & Mature & Senescent \\
\hline Upper & $(\mathrm{N}=239)$ & 22.2 & 46.4 & 31.4 \\
Mid-N & $(\mathrm{N}=200)$ & 14.0 & 54.5 & 31.5 \\
Mid-S & $(\mathrm{N}=71)$ & 22.5 & 31.0 & 46.5 \\
Lower & $(\mathrm{N}=38)$ & 44.7 & 21.1 & 34.2 \\
\hline
\end{tabular}

icantly higher grass cover than the other sites $(P<$ $0.0001)$. The upper site and the lower site, where Sophora regeneration was highest, contained lower grass cover overall than the two mid-elevation sites $(P<0.031)$.

\section{DISCUSSION}

Fifteen years after ungulate reduction began, we found Sophora regeneration occurring across the entire study area. Sapling densities, however, were higher in Myoporum-Sophora woodland than in Sophora woodland. Sophora sapling densities were not related to elevation, but were most strongly affected by site. Regeneration was much greater in the upper and lower sites than in the other sites. It was lowest in the mid-elevation north site where grass cover was highest and Myoporum was virtually absent. These local effects probably result from the intensity of browsing regimes in different areas and the subsequent colonization by alien grasses, which suppressed germination (Williams 1994). Physiological limitations may prevent exotic grasses from invading high elevation areas, allowing higher $S_{0}$ -

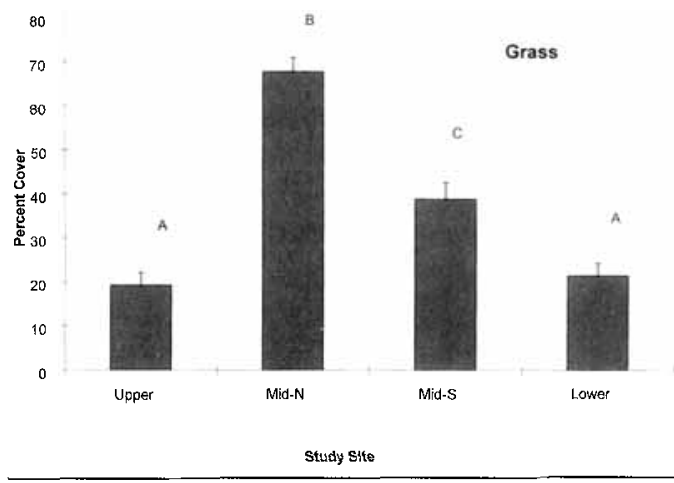

FIGURE 2. Mean percent grass cover by site and standard error on the west slope of Mauna Kea volcano, Hawaii. Means with the same superscripts are not significantly different ( $N=70 /$ site; Tukey grouping, $\alpha=0.05)$. 
phora regeneration. High elevation slopes may have been affected severely by a greater intensity of browsing if ungulates sought refuge from hunting after road access increased in the 1960s (Giffin 1976, 1982; Scowcroft \& Giffin 1983). The extreme climate near treeline, however, apparently does not affect regeneration as much as dense grasses in mid-elevation areas, where sapling densities measure less than one-third of the upper site.

An alternative that was not investigated is Sophora seed bank impoverishment in mid-elevation areas. Although Hartt and Neal (1940) and Scowcroft and Giffin (1983) stated that seeds of this species are widespread and remain viable in the soil for years, no studies have quantified soil seed bank or viability on Mauna Kea. Repeated mortality of seedlings caused by browsing and competitive interactions with other plants could result in exhaustion of the soil seed bank in areas of low mature tree density, where seeds are not continually replenished.

Sophora snag densities were not different among any of the sites. Because precipitation was not related to elevation (Juvik et al. 1993), we may assume that snags, which do not intercept substantial fog drip, decay, and fall at similar rates, suggest the species was more evenly distributed in the past. Sophora population recovery from browse damage, however, was not evenly distributed due to grass colonization or reduced seed bank in mid-elevation areas.

The low density of Sophora saplings in the midelevation sites relative to the other sites suggests that the Sophora woodland in these areas will continue to be less dense than in the other areas unless supplemental plantings are made. This area, which has a high density of Loxioides and a high nesting density, may be critically important for Loxioides, which occur in higher density in Sophora woodland than in mixed woodland (Hess et al., in press; Fig. 3). Supplemental plantings in areas formerly forested with Sophora, as recommended by Giffin (1982), may benefit Loxioides nesting success and juvenile survivorship, which are both positively correlated with Sophora pod production (Lindsey et al. 1995).

The upper and mid-elevation north sites were comprised almost exclusively of Sophora, while the mid-elevation south and lower sites contained a high proportion of codominant Myoporum, even though the two mid-elevation sites overlapped extensively in altitude. Van Riper (1980b) attributed this distinct distributional limit to substrate. Regeneration of Myoporum was less than one-tenth of

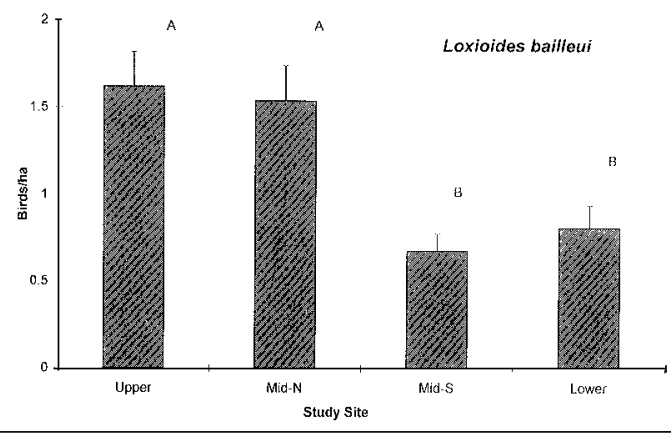

FIGURE 3. Mean density (no./ha \pm SE) of Loxioides bailleui per sampling station at four study sites on the west slope of Mauna Kea, Hawaii. Auditory counts ( $N=$ 40 stations/study site) sampled six times July 1994-August 1996. Means with the same superscripts are not significantly different (Tukey grouping, $\alpha=0.05$ ).

Sophora regeneration in the mid-elevation south and lower sites, and almost absent in the upper and mid-elevation north sites. Low Myoporum regeneration suggests that this species will become less dense in codominant areas, and will be replaced by Sophora as an apparent result of ungulate reduction (van Riper 1980b, Cuddihy \& Stone 1990). Mountainspring et al. (1987) also found Sophora regeneration, but low Myoporum regeneration after ungulate reduction. Other comparable subalpine woodland sites with high ungulate browsing pressure, such as Kipuka Alala on Mauna Loa, exhibit extremely high Myoporum regeneration concurrent with low Sophora regeneration (Banko 1997).

There was no evidence of a negative association between Sophora and mature Myoporum trees on the spatial scale of this study. Smaller-scale interactions may affect local establishment, but Sophora sapling densities were actually higher in mixed species woodland. This pattern of association suggests that competitive suppression by Myoporum is not as important in the establishment of Sophora as grasses. While Sophora facilitates grasses (Williams 1994), Myoporum apparently does not have the same effect. If Myoporum actually inhibits grasses, reduction of this species may lead to more extensive grass invasion in mixed woodland. In the Puu Ahumoa area of Mauna Kea, where swaths of mixed woodland have been cleared by bulldozers and invaded by grasses, there is no detectable regeneration of any trees. Reduction of Myoporum would not likely be as successful in enhancing Sophora woodlands or improving habitat for Loxioides as supplemental planting of Sophora combined with grass control. 
We observed extensive browse damage on $\mathrm{So}_{\text {- }}$ phora saplings and bark stripping on both Sophora and Myoporum in the vicinity of Puu Ulaula. Other native species with evidence of foliage browse damage include Chenopodium oahuense, Rumex gigantea, Dubautia spp., and Stenogyne microphylla. Native bunchgrass (Eragrostis sp.) clumps were also uprooted and flattened. The Ovis spp. population in this area has rebounded since the last major eradication effort in 1991. We regularly saw herds of 20-30 Ovis spp. at these two sites and herds of more than 50 on two occasions during this study. Both Ovis aries and $O$. musimon prefer Sophora (Giffin 1976, 1982), and there is currently a very large proportion of Sophora saplings and small young trees in this area that are within reach of browsing ungulates. Scowcroft and Conrad (1992) concluded that remaining Ovis spp. in Mauna Kea Forest Reserve could prevent the recovery of native species in areas where the animals concentrate.

Exotic species can irreversibly alter ecosystem processes such as fire regimes, change plant community composition, and cause faunal extinctions, not only on oceanic islands but also in continental areas (D'Antonio \& Vitousek 1992). The Hawaiian Islands may be particularly susceptible to these perturbations because of the scale of exotic species invasions relative to the size of land mass, inability of native plants to tolerate browsing (Scowcroft $\&$ Giffin 1983), fire (Hughes et al. 1991, Smith \& Tunison 1992), and loss of competitiveness (Carlquist 1970). Subalpine woodlands may be more capable of recovery after removal of browsing ungulates than submontane seasonally dry zones of Hawaii (Hughes et al. 1991). They, however, may require intensive management against alien grasses, which invade even relatively undisturbed areas of Hawaii and cause conversion from woodland to grassland (Hughes et al. 1991).

Invasive grasses in subalpine woodland have both competitive effects on establishment of native trees and ecosystem effects by altering fire frequen- cy and intensity (D'Antonio \& Vitousek 1992). After fires, germination of Sophora may be severely inhibited by grasses, which can recover quickly (Hughes et al. 1991, D'Antonio \& Vitousek 1992). Although some Sophora may resprout after fires, aboveground cover is reduced for at least five years (Smith \& Tunison 1992). Loxioides may require habitat that has recovered for a substantially longer time. More research is needed on the role of fire on Mauna Kea with respect to past and present levels of fuels and subalpine woodland regeneration.

The elimination of feral ungulates, as specified by the recovery plan (U.S. Fish and Wildlife Service 1986), will be necessary for reclamation of Loxioides habitat designated as critical. Supplemental plantings of Sophora saplings (Giffin 1982) may enhance habitat in areas of low density, but should not be attempted at all while large numbers of Ovis spp. persist on Mauna Kea. Grass control may be necessary in mid-elevation Sophora woodland to interrupt continuous fine fuels and to provide favorable germination and growth conditions for Sopho$r a$. It is not as important, however, in high elevation areas or in mixed species woodland, where grass cover is lower. Reduction of Myoporum is not likely to be as effective in enhancing habitat for Loxioides as the elimination of ungulates, supplemental planting of Sophora, reduction of grasses, and fire management.

\section{ACKNOWLEDGMENTS}

We would like to acknowledge the many NBS volunteers who helped in this study; R. Allen, C. Crooker, S. Dougill, K. Ellison, S. Howlin, A. Hurlbert, F. Keith, T. Kruger, S. Legare, T. Male, and D. Payne. Special thanks to $S$. Barker and $M$. Stapleton for organizing field crews, data entry, and serving as "Captain PCQ." Thanks to the State of Hawaii Division of Forestry and Wildlife for allowing us to work in the Mauna Kea Forest Reserve. Thanks to T. Lodge, R. Ostertag, T. Pratt, F. Putz, B. Woodworth, and two anonymous reviewers for helpful comments.

\section{LITERATURE CITED}

Amarastikari, P. 1993. Potential impact of mammalian predators on endemic forest birds of western Mauna Kea, Hawaii. Conserv. Biol. 7: 316-324.

Banko, P. C. 1997. Palila restoration project. Final report (phases 1-3). Report to U.S. Army and U.S. Fish \& Wildlife Service, Portland, Oregon.

Cakz.luist, S. 1970. Hawaii: a natural history. The Natural History Press, Garden City, New York.

Comlam, G., ANI J. T. CuRTis. 1956. The use of distance measurements in phytosociological sampling. Ecology 37: $451-460$.

CU1m1) HY, L. W., AND C. P. SrONE. 1990. Alteration of native Hawiian vegetation: effects of humans, their activities and introductions. University of Hawai' i, Honolulu, Hawaii. 
D'Antonio, C. M., and P. M. Vitousi:k. 1992. Biological invasions by exotic grasses, the grass/fire cycle, and global change. Annu. Rev. Ecol. Syst. 23: 63-87.

Gritin, J. G. 1976. Ecology of feral sheep on Mauna Kea. State of Hawaii, Dep. Land and Natu. Resour., Div. Forestry and Wildlife, Honolulu, Hawaii.

1982. Ecology of mouflon sheep on Mauna Kea. State of Hawaii, Dep. Land and Natu. Resour., Div. Forestry and Wildlife, Honolulu, Hawaii.

Hartt, C. E., and M. C. Nrnl. 1940. The plant ecology of Mauna Kea, Hawaii. Ecology 21: 237-266.

Hess, S. C., P. C. Bınko, M. H. Rirnoldos, G. J. Breinnek, L. P. Laniawr, and J. D. JAcom. In press. Drepanidae movements in relation to food resource availability in subalpine woodland on Mauna Kea, Hawaii. Stud. Avian Biol.

Hucilit:, F., P. M. VTrousek, ANo 'T. Tunison. 1991. Alien grass invasion and fire in the seasonal submontane zone of Hawaii. Ecology 72: 743-746.

Jacomi, J. D., S. G. Fancy, J. G. Girin, Ano J. M. Scorr, 1996. Long-term population variability in the palila, an endangered species. Pac. Sci. 50: 363-370.

JUVIK, J. O., AND S. P. JuvIK. 1984. Mauna Kea and the myth of multiple use: endangered species and mountain management in Hawaii. Mountain Res. and Dev, 4: 191-202.

, AND D. N a Hawaiian montane forest. In L. S. Hamilton, J. O. Juvik, and F. N. Scatena (Eds.). Tropical montane clond forests, pp. 102-113. East-West Center, Honolulu, Hawaii.

, D. Nunitir, P. C. Banko, and K. Hughes. 1993. Forest climatology near the tree line in Hawaii. Agric. and For. Meteor. 66: 159-172.

Lindesey, G. D., S. G. Fancy, M. H. Reynolids, T. K. Prati, K. A. Whl.son, P. C. Banko, and J. D. Jacolis. 1995. Population structure and survival of palila. Condor 97: 528-535.

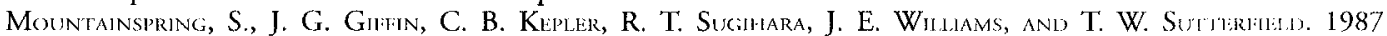
Regeneration of the subalpine woodland on Mauna Kea. U.S. Fish and Wildlife Service Report, Portland, Oregon.

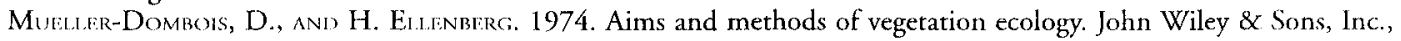
New York, New York.

Murpity, P. G., ANi, A. E. Luco. 1986. Ecology of tropical dry forest. Annu. Rev. Ecol. Syst. 17: 67-88.

Ol.SON, S. L., ANb H. F. James. 1982. Prodromus of the fossil avifauna of Hawaiian Islands. Smithsonian Contrib Zool. 365.

POLIARD, J. H. 1971. On distance estimators of density in randomly distributed forests. Biometrics 27: 991 1002.

SAS Instrum! INc: 1985. SAS user's guide, version 5 edition. SAS Institute Inc, Cary, North Carolina.

Scolot, J. M., S. Mountainspiejnc, F. L. Ramsiy, and C. B. Kisplis. 1986. Forest bird communities of the Hawaiian Islands: their dynamics, Ecology and Conservation. Stud. Avian Biol. 9: 1-431.

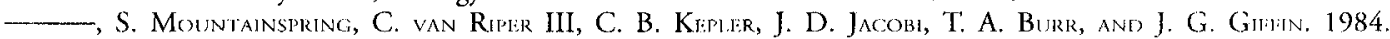
Annual variation in the distribution, abundance, and habitat response of the palila (Loxioides bailleut). Auk 101: 647-664.

Scowcroit, P. G. 1983. Tree cover changes in mamane (Sophora chrysophylla) forests grazed by sheep and cattle. Pac. Sci. 37: 109-119.

-, nN1. C. E. Conran. 1992. Alien and native plant response to release from feral sheep browsing on Mauna Kea. In C. P. Stone, C. W. Smith, J. T. Tunison (Eds.). Alien plant invasion in Hawaii: management and research in native ecosystems, pp. 625-665. University of Hawai'i Press, Honolulu, Hawaii.

$\longrightarrow$, AND J. G. Girifn. 1983. Feral herbivores suppress mamane (Sophora chrysophylla) and other browse species on Mauna Kea, Hawaii. J. Range Manage. 36: 638-645.

- AND H. F. SAKAI. 1983. Impact of feral herbivores on mamane forests of Mauna Kea, Hawaii: bark stripping and diameter class structure. J. Range Manage. 36: 495-498.

Smitr, C. W., Anis T. 'Tunison. 1992. Fire and alien plants in Hawait: research and management implications for native ecosystems. In C. P. Stone, C. W. Smith, and J. T. Tunison (Eds.). Alien plant invasion in Hawaii: management and research in native ecosystems, pp. 394-408. University of Hawai'i Press, Honolulu, Hawaii.

Strotz, D. F., J. W. Fitzjatrick, T. A. Parker III, and D. K. Moskovits. 1996. Neotropical birds: ecology and conservation. University of Chicago Press, Chicago, Illinois.

U.S. Fish and Windufe Skrvick. 1986. Recovery plan for the palila. U. S. Fish and Wildlife Service, Portland, Oregon.

VAN RIPER, C., III. 1980a. Observations on the breeding of the palila Psittirostra bailleui of Hawaii. Ibis 122: $462-$ 475.

- $1980 \mathrm{~b}$. The phenology of dryland forests of Mauna Kea, Hawaii, and the impact of recent environmental perturbations. Biotropica 12: 282-291.

Whrner, R. E. 1960. A forest dies on Mauna Kea. Pac. Discovery 13: 6-14.

WIItIAMs, A. C. 1994. Effects of non-native grasses on a dry subalpine forest native to Hawaii and a discussion of effects of canopy on understory productivity. M.S. Thesis, University of California, Berkeley, California.

Worne, E. W., ANr' J. Mortus. 1996. Geologic map of the island of Hawaii. U.S. Department of the Interior. U.S.G.S. Misc. Investigations Series, Reston, Virginia. 